CHAPTER FIVE

\title{
THE WISE PURPOSE AND ORIGIN OF EVIL
}

\section{Ibn Taymiyya and the Explanation of Evil in Islamic Theodicies}

The question of evil (sharr) in Ibn Taymiyya's writings has not received serious study. Before examining the pertinent texts, it will prove useful to fill in some background on how the preceding Islamic tradition explains evil. A common theme is the educational and disciplinary role of evil in advancing the religious life. Already noted in the Introduction were al-Màturīdīs view that evil is a tool of God's wisdom to lead humankind to knowledge of God's existence and the Sufi notion that evil and suffering are instruments of God's discipline on the spiritual path. Similar ideas are found in the free-will theodicy of the Mu'tazilī 'Abd al-Jabbār who maintains that God inflicts pain not only as punishment for sins but also for the purposes of testing, warning and deterring. ${ }^{1}$

In the best-of-all-possible-worlds theodicy of Ibn Sinnā, all things are good from the vantage point of the whole. Pure or absolute evil does not exist, but relative or partial evil does and is inherent in the perfection of the created order. In the section on providence in al-Shifäa Ibn Sinnā explains that evil, which he understands metaphysically as imperfection (naqs) and 'adam-a term that I will translate variously as "nonexistence," "privation" or "lack" - is necessary to some things for them to be what they are. By way of example, he argues that burning is necessary to the perfection of fire even if fire occasionally burns someone. If such things did not involve evil, they would in fact be something else, but they must exist as they are for the maintenance of the universal order. In addition to the nonexistence of absolute evil and the necessity of relative evil to the perfection of things, Ibn Sinna also speaks quantitatively about evil. He affirms that the amount of evil in the universe is very small compared to the great amount of good. ${ }^{2}$

\footnotetext{
${ }^{1}$ Heemskerk, Suffering in Mu'tazilite Theology, 151-6.

2 Ibn Sīnā, Al-Shifä: Al-Ilāhiyyāt (2), 414-422. Ibn Sīnā, "Al-Risāla al-'arshiyya," 16, also attributes wise purpose ( ikma) to evils. For further analysis of metaphysical evil in the thought of Ibn Sīnā, see Abū Zayd, Mafbüm al-khayr, 112-118, 152-159; and Inati, The Problem of Evil, 65-101. 
Other parts of the Islamic tradition elaborate further answers as to why evil is necessary for the best possible order. In Ihyyà 'ulüm al-dìn, al-Ghazāli roots the necessity of evil in the principle that things cannot be known except by their opposites. Health is not enjoyed without illness; the blessed in Paradise would not know their blessedness without Hell; and perfection is not known without imperfection. ${ }^{3}$ Ibn 'Arabī employs an additional explanation for evil, what Arthur Lovejoy in his classic The Great Chain of Being calls the "principle of plenitude," which locates the good in the greatest possible variety. ${ }^{4}$ For Ibn 'Arabī, God bestows existence on the cosmos for the great good of making Himself known. Evil and imperfection, which are paradoxically no more than privation and otherness from the sole reality of God and yet real in that they thwart God's Law and human purposes, are necessary in order to afford God the possibility to manifest the infinite diversity, the great plenitude, of His names. Everything in existence reflects a divine name such as All-Merciful, Giver of Life, Giver of Death, Honorer, Humiliator and so forth. These names extend in number beyond the traditional ninety-nine to infinity. Nonetheless, Ibn 'Arabì maintains that, out of courtesy for God, we should address God only with names that He has revealed. We should not, for example, call God Liar or Ignorant. ${ }^{5}$

The principle of plenitude and the idea that things are known only by their opposites do not appear explicitly in Ibn Taymiyya's thought on evil, but he does speak of evil's educational qualities, its logical necessity in the nature of the world, its relativity and its quantitative insignificance. However, congruent with his juridical concern to speak well of God, the shaykh's primary interest is finding ways not to attribute evil to God even though it is God who is ultimately responsible for the world being the way it is. In the end his refuge is God's wise purpose.

The first section below examines Ibn Taymiyya's three-fold typology for attributing evil. This includes discussion of his views on God's names. The second section investigates the degree to which he believes that God's wise

${ }^{3}$ Al-Ghazālī, Ihyyà 'ulüm al-dìn, 4:258-9 (at the end of "Kitāb al-tawhìd wa al-tawakkul"). Ormsby, Theodicy, 40 and 64-9, provides a translation and analysis of this text. The idea that things are known through their opposites is also found in al-Halläj and others, especially in reflection on the fate of Ibliss. On this, see Awn, Satan's Tragedy and Redemption, 122-150.

${ }^{4}$ Arthur O. Lovejoy, The Great Chain of Being: A Study of the History of an Idea (Cambridge, MA: Harvard University Press, 1936), 52ff.

5 Chittick, The Sufi Path of Knowledge, 33-44, 289-297. For briefer treatment of these themes, see William C. Chittick, Imaginal Worlds: Ibn al-'Arabi and the Problem of Religious Diversity (Albany, NY: State University of New York Press, 1994), especially Chapters 2, 3 and 8 . 
purposes may be known and his few suggestions as to what they are. The third section shows how Ibn Taymiyya employs the metaphysical concept of evil as nonexistence for moral and religious ends in Hasana and Fätiha.

\section{Ibn Taymiyya's Evil Attribution Typology}

\section{Attributing Evil to the Generality, the Secondary Cause or the Elided Agent}

In Minhäj, Iräda, Kasb, Jabr, Hasana and a few other texts Ibn Taymiyya asserts that evil must not be attributed directly to God but rather in one of three other ways, which he presents in a recurring typological form. ${ }^{6}$ This three-fold typology appears in diverse contexts with varying degrees of fullness. Occasionally, it appears as a hermeneutic grid comprehending the ways that evil is attributed in the Qur'an or in both the Qur'an and the Sunna. Most often, however, the shaykh cites it as a general statement of how evil is attributed. In the first type evil "falls within the compass of the generality ('umüm) of created things," or "falls within the compass of the generality," or, more tersely, is attributed "by way of the generality." In the second type, evil is attributed to its secondary cause (sabab), its agent cause (al-sabab al$\left.f_{\bar{a}} \bar{i} i\right)$ or the creature (makblüq). In the third type, evil is mentioned without reference to its agent.

\section{The Attribution of Evil in the Qur'an}

Although Ibn Taymiyya gives very little direct explanation of the three types in the evil attribution typology itself, he usually supplies examples of each from the Qur'an. As an example of the first type in which evil is attributed to the "generality," the shaykh customarily cites, "God is the Creator of everything" (Q. 13:16, 39:62), or, "He has created everything" (Q. 25:2). These verses do not explain what it means for evil to fall "within the compass of the generality" except to direct attention away from God's creation of evil specifically and to His creation of all things in general. More will be said about the interpretation of this type below. The attribution of evil to its

${ }^{6}$ Iräda, MF 8:93-7; Kasb, MF 8:400-1; Tä́ $a$, MF 8:446-7; Jabr, MF 8:511-2; Fätiha, MF 14:21; Hasana, MF 14:265-6; Thulth, MF 17:94-6, 99; and Minhäj, 3:142-5/2:25-6, 5:408-411/3:102.

7 In the Qur'an in $T \bar{a}^{-} a$, MF 8:447, and in both the Qur'an and the Sunna in Iräda, MF 8:94; and Jabr, 8:511. 
secondary cause, that is, the creature, is more obvious, and, as an example, Ibn Taymiyya often cites, "Say, 'I seek refuge with the Lord of the daybreak from the evil of what He has created"' (Q. 113:1-2), that is, from the evil instigated by God's creatures. The shaykh's standard example of the third type is the quranic statement about the jinn: "We do not know whether evil is willed for those in the earth or whether their Lord wills rectitude for them" (Q. 72:10). Here, the agent willing evil, presumably God, has been elided and the verb "to will" put in the passive voice.

In the two instances of the typology in Minhäj, Ibn Taymiyya observes that all three types are found in the first chapter of the Qur'an: "Guide us in the Straight Path, the path of those whom You have blessed, not those upon whom is anger, and not those who went astray" (Q. 1:6-7). ${ }^{8}$ In these verses, God is the agent $\left(f_{\bar{a}}^{-c} i l\right)$ of blessing (first type). The agent of anger has been elided (third type), and the evil of going astray is attributed to creatures themselves (second type). The shaykh also gives this illustration in Jabr, but he presents the earlier verse, "Praise be to God, Lord of the worlds" (Q. 1:2), as the example of the first type." Ibn Taymiyya provides no additional quranic examples of the first and third types. Moreover, the third type receives no further discussion at all. Elision of the agent of evil is no more than a rhetorical device or form of courtesy that the shaykh finds the Qur'an using to avoid attributing evil to God.

In Iräda the shaykh gives several more quranic examples of attributing evil to human secondary causes: "Our Lord, we have wronged ourselves" (Q. 7:23); "When an affliction comes to you, even after having dealt one out twice as great, you say, 'From where does this come?' Say, 'It is from yourselves'" (Q. 3:165); and "Any good thing that comes to you is from God, and any evil thing that comes to you is from yourself" (Q. 4:79). ${ }^{10}$ Elsewhere, he adds Abraham's attribution of illness to himself but the cure to God: "And when I am ill, He cures me" (Q. 26:80). ${ }^{11}$ Ibn Taymiyya also illustrates the attribution of evil to its secondary cause with brief quotations

\footnotetext{
8 Minhäj, 3:143/2:25 and 5:410/3:102. English translations of ghayr al-maghdūb 'alayhim as "not (the way) of those who have earned Your Anger" (Hilālī and Khān), "not of those against whom Thou art wrathful" (Arberry) or "Not (the path) of those who earn Thine anger" (Pickthall) do not accurately translate the Arabic by obscuring the fact that no agent of anger is mentioned in the text.

9 Jabr, MF 8:511. Ibn Taymiyya also mentions in Hasana, MF 14:272, that the threefold evil attribution typology is found in the first chapter of the Qur'an, but he does not explain beyond the first type.

${ }_{10}$ Iräda, MF 8:95.

${ }^{11} \mathrm{Jabr}$, MF 8:511; Kasb, MF 8:401; and Minhāj, 3:143/2:25, 5:410/3:102.
} 
from the quranic story of the guide who led Moses through three ordeals (Q. 18:60-82). ${ }^{12}$ When explaining the reasons for his puzzling actions, the guide, whom Ibn Taymiyya takes to be the mythical Khidrr, attributes his prima facie evil acts of sinking a boat and killing a boy to himself but attributes his good act of straightening a leaning wall to God. These verses concerning Abraham and Khiḍr show not only that evil is attributed to creatures but also that good comes from God. The human agent gets sick, sinks a boat and kills, but God rights a leaning wall and cures the sick.

\section{Evil Is Good in God's Wise Purpose, and Good Far Exceeds Evil}

As mentioned above, Ibn Taymiyya does not clearly specify what he means in the first type of the evil attribution typology by evil falling "within the compass of the generality of created things." ${ }^{13}$ However, the contexts of these typologies elaborate this in three different ways that echo Ibn Sinnā. First, from God's perspective, the generality of what God creates is wholly good; evil is relative and exists only from the perspective of creatures. Second, evil is a necessary concomitant of the perfection of the created order. Third, from the human perspective, the generality of good is far greater in quantity than evil.

In the first of these three ways, Ibn Taymiyya maintains that what creatures regard as evil is good by virtue of God's wise purpose. The following from Minhäj is typical: "If God-Exalted is $\mathrm{He}$-is Creator of everything, He creates good (khayr) and evil (sharr) on account of the wise purpose that He has in that by virtue of which His act is good (basan) and perfect (mutqin)."14 A nearby passage extends this to more unseemly things: "God is Creator of illnesses, aches, hateful odors, ugly forms and noxious bodies like snakes and human excrement on account of a profound wise purpose in them." ${ }^{15}$ In Hasana, the shaykh underscores that what makes all God's

${ }_{12} \mathrm{Jabr}, \mathrm{MF}$ 8:512; and Irāda, MF 8:95.

13 Irāda, MF 8:94.

${ }_{14}$ Minhäj, 3:142/2:25.

${ }_{15}$ Minhāj, 3:144/2:25. Ibn Taymiyya, Minhäj, 3:144-5/2:25, clarifies that these things, as with everything else that God creates, come neither from God's essence nor from His command. In the same passage the shaykh tersely explains that everything that God creates is good "according to the two doctrines of 'delegation' and 'causality' ('alà qawlay al-tafwìd wa al-ta'lill)." I understand this to mean that God's creation of evil is not evil on His part because of His delegation of it to a creature or secondary cause and by virtue of the final causality in His will, that is, His wise purpose in creating it. 
deeds good is wise purpose while what makes human evil deeds evil is a lack of wise purpose. ${ }^{16}$

Ibn Taymiyya grounds the doctrine of God's wise purpose in quranic texts showing that all God's creative acts are good and true. Most commonly, he cites, "The handiwork of God who perfected everything" (Q. 27:88), and, "Who made good everything He created" (Q. 32:7). ${ }^{17}$ In Fätiha he adds, "We did not create the heavens and the earth and what is between them except with truth" (Q. 15:85), and, "[Those who] reflect on the creation of the heavens and the earth, [saying], 'Our Lord! You have not created this in vain"” (Q. 3:191). ${ }^{18}$ These last two verses and several others denying aimlessness and vanity in God's creative work are given in Thulth, a commentary on Surat al-Ikhlās (Q. 112) that will be discussed at greater length below. ${ }^{19}$ In several places, the shaykh also quotes the hadith, "Good is in Your hands, and evil is not [attributed] to You," to affirm the goodness of all that God does. ${ }^{20}$

In view of the complete goodness of the evil that God creates, Ibn Taymiyya notes in the contexts of the evil attribution typology in Iräda, Jabr, Hasana and Fätiha that God does not create evil that is absolute (mutlaq), general ('ämm), total (kullī) or pure (mahd). Rather, the evil that God cre-

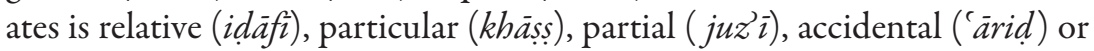
restricted (muqayyad). ${ }^{21}$ Evil is thus evil relative only to those who commit it or suffer its harm. The following passage from Hasana gives concise expres-

16 The text in Hasana, MF 14:275, reads: "[God] created [an evil deed] only for a wise purpose. It is not attributed to Him in respect to its being an evil deed (sayyi a). Rather, it is attributed to the person (nafs) who commits evil (sharr) by it without wise purpose. She deserves to have evil and an evil thing attributed to her. In what she commits of sins, she does not aim at a good on behalf of which committing it is preponderant. On the contrary what is like this is in the category of good things. Therefore, the act of God is good ( hasan). He never does a bad thing (qabì ) or an evil deed."

${ }_{17}$ Minhāj, 3:142/2:25, 5:409/3:102; Irāda, MF 8:94; Jabr, MF 8:512; and Fätiha, MF 14:21.

${ }^{18}$ Fätiha, MF 14:21.

19 Thulth, MF 17:95-6, 99. The additional references are Q. 6:73, 15:85-6, 21:16-7, 23:115, 38:27, 44:39 and 75:36.

${ }^{20}$ Kasb, MF 8:400; Jabr, MF 8:511; Fätiha, MF 14:18; Hasana, MF 14:266; Thulth, MF 17:94; and Minhāj, 5:409/3:102. The hadith is found in Muslim, 1290, Șalāt al-musāfirīn wa qașruhā, Al-Du'ā' fị șalāt al-layl wa qiyāmihi. Ibn Taymiyya, Minhāaj 5:409/3:102, notes that the latter part of this saying, wa al-sharr laysa ilayk, is subject to more than one interpretation. It has been understood to mean either that one cannot draw close to God with evil deeds or that evil is not attributed to God. In Thulth, MF 17:94, he also adds the possibility that it means "evil is nonexistence ('adam) or among the concomitants of nonexistence." The shaykh does not rule out any of these interpretations, but I have chosen to translate the saying as denying evil's attribution to God because that befits the context.

${ }_{21}$ Iräda, MF 8:94; Jabr, MF 8:512; Hasana, MF 14:266, 270; and Fätiba, MF 14:20-1. 
sion to these ideas using several of the aforementioned terms: "[God] does not create pure evil. Rather, in everything that $\mathrm{He}$ creates is a wise purpose by virtue of which it is good. However, there may be some evil in it for some people, and this is partial, relative evil. As for total evil or absolute evil, the Lord is exonerated of that."22

In Fatiha the shaykh employs the relativity of evil to interpret exhortations to believe in both the good and evil of God's determination. He relates, for example, a hadith transmitted by Abū Dāwūd, "If you had disbursed [in alms] a whole earth full of gold, [God] would not have accepted it from you until you had believed in determination, its good and its evil." ${ }^{\prime 23} \mathrm{Ibn}$ Taymiyya explains that the evil mentioned here is only evil for the person who suffers pain under it and that what is evil for one may in fact be a blessing for another: "When evil afflicts the servant, the heart of his enemy is glad. It is good for the one and evil for the other. There is no good and no evil with respect to one who has no friend and no enemy."24 In this view, evil is associated with pain and disadvantage to a particular individual, whereas, from God's perspective, everything is good.

In Hasana Ibn Taymiyya links Aristotelian causal terminology to the first two types in his three-fold evil attribution typology. This further illustrates how he folds evil into God's general and complete goodness: "[Evil] is not attributed simply to God-Exalted is He-[but it is attributed] in two respects: in respect to its final cause (al-illa al-ghä iyya) and in respect to its secondary cause (sabab) and agent cause (al-illa al-fä́liliyya)."25 Ibn Taymiyya then equates the philosophical term final cause with wise purpose, and he asserts that God does not create pure evil in which there is no wise purpose or mercy. He explains that mentioning evil with respect to God's activity must always be done in the proper context of God's more general wise

${ }^{22}$ Hasana, MF 14:266. Cf. Hasana, MF 14:268. In Jabr, MF 8:512, the shaykh makes the same point: "The created thing is good and wise by virtue of the wise purpose for which it was created even if there is evil in it in another respect. This is something accidental and partial that is not pure evil. Rather, evil through which preponderant good is intended is good coming from the Wise Agent, even if it is evil for the one in whom it subsists." In Fätiha, MF 14:21, Ibn Taymiyya explains: "God did not create anything except for a wise purpose. This wise purpose is its aspect of goodness (busn) and good (khayr). In created things, there is no pure evil in which there is no good and in which there is no advantage in any respect."

${ }^{23}$ Fätiha, MF 14:20. The hadith is found in approximately this form in Abū Dāwūd, 4077, Al-Sunna, Fī al-qadar.

${ }^{24}$ Fätiba, MF 14:21.

${ }^{25}$ Hasana, MF 14:299. Ibn Taymiyya structures a major portion of Hasana around these two causes: MF 14:299-315 is headed by discussion of the final cause, and MF 14:315-331 begins with the agent or secondary cause. However, the text meanders, and the shaykh does not confine himself to direct exposition of these two causes in the course of these pages. 
purpose. For example, he argues that it is wrong merely to say, "Muhammad and his nation spill blood and spread corruption in the earth," because this is subjecting them to blame. Rather, one should say, "They undertake jihad in the way of God in order that the word of God be highest and all religion be for God, and they kill whoever obstructs them from that." ${ }^{26}$ Likewise, it is erroneous to say that God creates evil that is of no profit to anyone. Instead, one should affirm that God in His wisdom has created everything good and that "He has in what He creates of pain or blameworthy deeds in living beings a great wise purpose and a momentous blessing." ${ }^{.7}$ By placing the focus on God's goodness and wise purpose first, any accompanying evil finds its place as evil relative only to particular creatures. Moreover, this relative evil is wholly good by virtue of God's wise purpose.

In a discussion linked to the evil attribution typology in Hasana, Ibn Taymiyya complains that two groups go astray on this issue. The first group, seeking to protect God from doing bad deeds, denies that God wills all things or creates human acts, while the second group asserts that God may create evil without a wise purpose. ${ }^{28}$ Although unnamed, the two groups are obviously the Mu'tazilīs and the Ash'arīs, respectively. Ibn Taymiyya observes that both groups do not adequately distinguish particular evil from general evil or relative evil from absolute evil. They conceive evil solely in an absolute sense that applies equally to creatures and the Creator but fail to grasp that evil is only evil relative to creatures. He gives the case of lying prophets as further evidence that God does not create general evil. In His wise purpose, God may lead some people astray, but His wise purpose precludes confirming lying prophets with miracles because that would show God to be weak and unable to differentiate truth-tellers from liars. For God to support a lying Prophet with the same miracles with which He supports truth-telling prophets would be a general evil..$^{29}$

Ibn Taymiyya's second way of making sense of what it means for evil to fall under the generality of created things is to argue that evil is logically necessary to the perfection of creation. The shaykh does not elaborate on this extensively, but in Jabr he does broach the question why God's wise purpose could not have been achieved apart from any evil whatsoever. He explains that the question reveals a lack of knowledge of the reality and

\footnotetext{
26 Hasana, MF 14:300.

27 Hasana, MF 14:300.

28 Hasana, MF 14:266-7.

29 Hasana, MF 14:268, 270-1.
} 
interconnectedness (irtibāt) of things. Much in the fashion of Ibn Sinnā, Ibn Taymiyya argues that God is bound by logical constraints: "When God creates something, He must inevitably create its necessary concomitants." ${ }^{30}$ God cannot join two contraries at one time, and He cannot create what is impossible. God cannot, for example, make someone simultaneously a believer and an unbeliever, even if He can join together a measure of belief and hypocrisy in the same person. Ibn Taymiyya adds that God's attributes of knowledge, power, wisdom and mercy are of the utmost in perfection and that such perfection is necessary for the Lord. ${ }^{31}$ The implication is that this world with its relative evil is the best possible in the divine perfection and that evil is necessary to the achievement of God's purpose. Ibn Taymiyya affirms that this is the best possible world explicitly in 'Adil, which will be discussed in Chapter Six.

Ibn Taymiyya's third way of elaborating the sense in which evil is attributed by way of the generality is illustrated in a text from Fätiha. Here, even from the human perspective, evil is minimal in comparison to the great amount of good that God creates:

In the things that God creates there is nothing that always inflicts pain on all creatures, and there is nothing that always inflicts pain on most of them. On the contrary, the things that He creates bless them, or most of them, most of the time, like the sun and health. There is nothing among the existent things which God creates that is evil absolutely [and] generally. It is known that created, existent evil is restricted, particular evil. There is another aspect by which it is good and a good thing and which is the preponderant of the two aspects. $^{32}$

Quantitative analysis of evil on the creaturely plane is also found in Irada, where Ibn Taymiyya opens a discussion of evil by affirming that God has a wise purpose in the generality of what He creates: "The general things that [God] does are for a general wise purpose and general mercy, as, for example, the sending of Muhammad-God bless him and give him peace." ${ }^{33}$ Then the shaykh broaches a peculiar problem of evil involving the Messenger and provides two quantitative responses:

Jabr, MF 8:512.

Jabr, MF 8:512-3.

2 Fätiha, MF 14:21.

33 Iräda, MF 8:93. Ibn Taymiyya backs this up with several quranic references: "We have not sent you except as a mercy to the worlds" (Q. 21:107) and Q. 3:144, 3:164, 6:53 and 14:28. 
When someone says, "A group of people like those from among the associationists and the People of the Book who considered [the Messenger] a liar were harmed by his message," there are two answers to this. ${ }^{34}$

The first of them is that he profited them to the extent possible. He weakened their evil that they were committing. [What would have happened] had it not been for the message with the manifestation of arguments and signs that made what was in their hearts tremor and with jihad and the poll tax that frightened them and humiliated them until their evil decreased? Whomever he killed among them died before his life grew long in unbelief and his unbelief became greater. Thus, this was a reduction of his evil. The messengers-God bless them-were raised up to obtain benefits and perfect them and to strip away detriments and reduce them to the extent possible.

The second answer is that whatever harm occurred is a minuscule thing beside whatever profit occurred. An example is the rain whose profit is general even if some houses are destroyed by it and some travelers and laborers, like the fullers and their like, are held up by it. Something whose profit and benefit is general is an intended good and beloved mercy even if some people are harmed by it. Certain groups of the Muslims, the Kalām theologians, the jurists and others among the Hanafis, the Hanbalīs and others, and among the Karrāmīs and the Sufis give this answer, and it is the answer of many of the philosophers. ${ }^{35}$

In this text, Ibn Taymiyya's first argues that the Prophet reduced evil to the extent possible and even cut short the lives of unbelievers for their own good. The shaykh argues similarly in Hasana that the great good and happiness rendered by Muhammad's message bear no relation to the limited misery and partial evil suffered by the Arab associationists and the unbelieving People of the Book. ${ }^{36}$ The second answer in the above passage explains that the evil incurred by rain is a small price to pay for the much greater good obtained through it. Both answers appeal to the quantitative insignificance of evil on the plane of human affairs.

\section{The Relation of God's Names to Evil}

An illustrative component accompanying several instances of the evil attribution typology is consideration of God's names. Following the pattern of the second type, Ibn Taymiyya sometimes excludes evil from God's names entirely and locates it in created things. The following from Iräda is typical: "There

\footnotetext{
${ }^{34}$ Fakhr al-Dīn al-Rāzī also takes up this question in his Tafsìr, 22:230-1, on Q. 21:107.

35 Iräda, MF 8:93-4. See also Hasana, MF 14:268, for the claims that rain and the sending of a messenger are general goods.

${ }^{36}$ Hasana, MF 14:276-7.
} 
is no name among the most beautiful names of God that entails evil. Evil is only mentioned in the things that He enacts (maf' $\bar{u}$ latibi). ${ }^{37}$ The shaykh supports this with several quranic verses in which the evils of punishment and chastisement are clearly distinguished from God's names: “Tell My servants that I am the Forgiving, the Compassionate and that My chastisement is the painful chastisement" (Q. 15:49-50); "Your Lord is swift in punishment, and He is the Forgiving, the Compassionate" (Q. 6:165); "Know that God is severe in punishment and that God is Forgiving, Compassionate" (Q. 5:98); "Truly, the grip of your Lord is severe. Truly, He it is Who begins and returns, and He is the Forgiving, the Loving" (Q. 85:12-4). ${ }^{38}$ In Thulth Ibn Taymiyya provides additional interpretation: "[God] regarded forgiveness and mercy to be among the meanings of His beautiful names with which He names Himself... As for the punishment that connects to servants, this is a creation of His, and it is this which is painful. He did not say, 'Truly, I am the Chastiser."' ${ }^{39}$

In both Iräda and Thulth, Ibn Taymiyya takes up the name Avenger (alMuntaqim) because it contradicts his claim that God's names involve no mention of evil. Although this name appears in the Qur'an, Ibn Taymiyya explains that it is qualified (muqayyad) by something in the immediate quranic context: "From the criminals We are avenging (muntaqimün)" (Q. 32:22); and "God is All-Mighty, possessor of vengeance (dhü intiqäm)" ( $\mathrm{Q}$. $3: 4) .{ }^{40}$ The shaykh does not clarify what these qualifying elements are, but the reader is left to assume that God's vengeance is limited to "the criminals" in the first example and subsumed under God's name All-Mighty in the second. Ibn Taymiyya also argues that Avenger is not one of the established beautiful names of God and that the hadith in the collection of al-Tirmidh ${ }^{-41}$ listing Avenger as an independent and unqualified name of God does not come from the Prophet himself. ${ }^{42}$

Even though Ibn Taymiyya excludes evil completely from God's names in some passages, he explains in other places that evil is suggested in the

${ }^{37}$ Iräda, MF 8:96. Cf. Täa a, MF 8:447; Thulth, MF 17:94; and Minhāj, 3:143/25:2.

38 Iräda, MF 8:96.

39 Thulth, MF 17:94-5.

${ }^{40}$ Ibn Taymiyya also mentions that Avenger is a qualified name in Hasana, MF 14:276.

${ }^{41}$ Tirmidhī, 3429, Al-Da'awāe 'an rasūl Allāh, Mā jā̀a fì 'aqd al-tasbìh bi-l-yad.

42 Iräda, MF 8:96-7; and Thulth, MF 17:95. Ibn Taymiyya, Iräda MF 8:97, adds that the only other hadith listing the ninety-nine names of God, that of Ibn Māja, 3851, Al-Du'à', Asmä' Allāh 'azza wa jalla, has a weak chain of transmission. Elsewhere, the shaykh, MF 22:481-6, explains that "ninety-nine" is simply a large number and does not actually indicate the exact number of God's names. In his view, the Qur'an and the Sunna supply more names than those listed in the two hadiths transmitted by Tirmidhī and Ibn Māja. 
mention of some of the names but that these names are then conjoined with other names having positive significance. Ibn Taymiyya usually takes up the conjoined names under the rubric of the first type in the evil attribution typology. An excerpt from Minhajj provides one of the shaykh's fuller explanations of this:

If [God] is mentioned by His particular (khässs) name, it is conjoined with the good, as He says in His most beautiful names: the Harmer/the Profiter (al-Dârr al-Näfí), the Giver/the Impeder (al-Mu'tī al-Mãni $\left.{ }^{\top}\right)$, the Abaser/the Exalter (al-Khäfid al-Räfí), and the Honorer/the Humiliator (al-Mu'izz al-Mudhill). He combines the two names because of the generality and inclusiveness in this, which indicates His unity. ${ }^{43}$

Apparently reticent to implicate the names Harmer, Impeder, Abaser and Humiliator in evil directly, Ibn Taymiyya instead labels them "particular" names. These are then conjoined to Profiter, Giver, Exalter and Honorer, respectively, to mitigate their severity and point to the general and all-inclusive creative work of God. A brief explanation of the conjoined names in Iräda concurs with this interpretation: "Neither the name Impeder is isolated from its conjoint nor Harmer from its conjoint because their conjunction indicates the generality." ${ }^{4}$

There is tension in Ibn Taymiyya's thought on the conjoined names between affirming that God in His various names relates to everything in existence, including evil, and maintaining that all of God's names imply only good. This comes out clearly in accompanying discussions of God's grace and justice in Iräda, Minhāj and Thulth. ${ }^{45}$ Only the fullest treatment, that in Thulth, will be discussed here. Ibn Taymiyya argues in Thulth that one part of God's Word, namely, Surat al-Ikhlās (Q. 112), which is said to be equivalent to one-third of the Qur'an, can be better than another. To support his point, he notes that some of God's attributes are preferable to others, as in the divine saying, "My mercy precedes My anger." ${ }^{46}$ Ibn Taymiyya then extends the principle of preference to God's hands. While there are hadiths which say, "Both of His hands are right [hands],"47 because "left" implies deficiency and there is no deficiency in the hands of God, there is another

${ }_{43}$ Minhäj, 5:410/3:102. Three of these pairs of conjoined names are also mentioned in Hasana, MF 14:276.

${ }_{44}$ Iräda, MF 8:95.

45 Iräda, MF 8:95; Minhāj, 5:410-1; and Thulth, 17:91-4.

${ }^{46}$ Bukhārī, 6998, Al-Tawhīid, Qawl Allāh ta ālā bal huwa Qửān majīd fì lawh maḥfūz; Muslim, 4940.

${ }_{47}$ Muslim, 3406, Al-Īmān, Faḍilat al-imām al-'̄àil wa 'uqubāt al-jāìir...; Aḥmad, 6204. 
hadith which indicates that one of God's hands is preferable to the other: "The right hand of God is full, and spending liberally day and night would not diminish it. Have you not seen what $\mathrm{He}$ has spent since the creation of the heaven and the earth? What is in His right hand has not diminished. In His other hand is justice; He abases and exalts." ${ }^{38}$ Ibn Taymiyya understands this to mean that grace is in God's right hand and justice is in His other, and he adds that it is known that grace is preferable to justice. Yet, in the event that God's justice should suggest that God commits evil, the shaykh quickly shifts from God's perspective to that of creatures and adds, "Evil does not appear in His names. It appears only in the things that He enacts," and he then sets out the evil attribution typology: "[Evil] is not attributed to Him except by way of the generality, by its attribution to the created cause or by the elision of its agent." ${ }^{49}$

In sum Ibn Taymiyya fluctuates between the first and second types of evil attribution when discussing God's names. Sometimes, he treats the names according to the first type, allowing that some of the names imply evil and asserting that these must be conjoined to, that is, subsumed under the generality of names carrying positive connotations. At other times, he completely denies any implication of evil in God's names and attributes evil solely to what God creates in creatures. As just observed from Thulth, he also switches easily from the first to the second type for the sake of the rhetorical propriety of speaking only of God's goodness.

Although Ibn Taymiyya resembles Ibn 'Arabī in suggesting that creation reflects the diversity of God's names, the shaykh's ideas are far less developed. More importantly, Ibn Taymiyya does not follow Ibn 'Arabī and his devotees in employing the image of God's two hands to elaborate a yang/yin dialectic in God's names or between God and creation. ${ }^{50}$ While Ibn Taymiyya similarly links God's names to good and evil in created reality, he does not mention that this relationship is in any way paradoxical. His primary concern is to avoid attributing evil to God by classifying the diverse data of revelation into the categories of his evil attribution typology. Yet, the fact that his typology is a typology and not a rational resolution implicitly acknowledges a duality of perspective. God's perspective of the generality and wise purpose does not

\footnotetext{
${ }^{48}$ Muslim, 1659, Al-Zakāh; Al-Ḥathth 'alā nafaqa... (The text is not identical); Bukhārī, 6869. Cf. Q. 5:64.

49 Thulth, MF 17:91-4.

${ }^{50}$ On the dialectical or yang/yin interplay of God's two hands in Ibn 'Arabī and his disciples, see Sachiko Murata, The Tao of Islam (Albany, NY: State University of New York Press, 1992), 88-114.
} 
negate that evil is still evil relative to creatures, and the evil perpetrated and experienced by creatures at the level of secondary causes does not nullify the goodness of God. The one perspective cannot be reduced to the other. The following two sections examine how Ibn Taymiyya fills out these two perspectives, first, by articulating God's wise purposes in creation and, second, by seeking to root the cause of evil in humans.

\section{Ibn Taymiyya on God's Wise Purposes in the Creation of Evil}

Ibn Taymiyya consistently argues that God has wise purposes in all that $\mathrm{He}$ creates, but he does not often ask what those purposes are, and he sometimes presents little hope that human beings can discover them. In Kasb, for example, he indicates that God has a well-guarded secret in His determination. It is enough to know that God is knowing, wise and merciful. ${ }^{51}$ In Iräda Ibn Taymiyya says that it is sufficient for people to know in general (min haythu jumla) that God has a great wise purpose in both His creation and His command. Yet, he also promises deeper insight for those who grow in faith. The function of this insight is to confirm God's revelation and God's reality:

Each time [the servant] increases in knowledge and faith, some of God's wisdom and His mercy will appear to him that will dazzle his intellect. This will make evident to him to count as true that about which God has informed in His Book, "We will show them Our signs on the horizons and in themselves until it becomes evident to them that He is the Real" (Q. 41:53).52

In Minhäj the shaykh's attitude varies from exhortation against asking questions to suggesting reasons for God's creation of illness and oppression. At one point, he says that it is not for us to ask God "Why?" and he quotes the verse, "God is not questioned as to what He does, but they are questioned" (Q. 21:23). ${ }^{53}$ At another place, he states without further comment that some people may know the wise purposes while others may not. ${ }^{54} \mathrm{~A}$ third passage in Minhāj illumines the human relationship to God's wisdom by comparing our knowledge of God's wise purpose to the ordinary person's awareness of a specialist's knowledge. A non-specialist can recognize that someone is an

${ }^{51}$ Kasb, MF 8:399.

52 Iräda, MF 8:97.

3 Minhäj, 3:67-8/2:5.

${ }^{4}$ Minhäj, 1:146/1:35. 
expert in grammar, mathematics, jurisprudence or medicine without being able to understand everything the expert says. Likewise, God's wisdom and mercy can dazzle minds and lead human beings to accept that God is wise and merciful without their understanding God's wise purpose. ${ }^{55}$ Despite this, another passage from Minhäj already noted in Chapter Three reveals more. Ibn Taymiyya says that one cannot know the detail of God's wise purpose, but he does note that, generally speaking, God's creation of illness and oppression leads to humility, repentance from sins and other religious virtues that cannot be attained except by way of difficulty. These evils are preconditions to greater goods that could not otherwise exist. ${ }^{56}$

In $J a b r$, when leading into a mention of the evil attribution typology, the shaykh asserts, “'[God] is not questioned as to what He does' (Q. 38:27). [This is] because of the perfection of His wise purpose, His mercy and His justice, not merely because of His subjugation and His power, as Jahm and his followers say." ${ }^{57}$ The exhortation not to question God would appear to bar any knowledge of God's wise purpose. However, very soon thereafter, Ibn Taymiyya turns quite gnostic, opening the door to knowledge of God's wise purposes for certain spiritually sensitive people:

Some servants may know some of [God's] wise purpose, and what is hidden of it may be hidden from them. People are favored over others in knowledge of His wise purpose, His mercy and His justice. Each time the servant increases in knowledge of the realities of things, he increases in knowledge of God's wise purpose, His justice, His mercy and His power. ${ }^{58}$

Ibn Taymiyya then explains that what the servant comes to understand is that even though God creates and determines all things and that his good deeds come from God, his evil deeds still come from the imperfection and ignorance of his soul (nafs) and God is just in punishing him. It is not clear how this existential knowledge of one's place before God represents knowledge of His wise purpose except possibly that God's wise purpose is that one comes to this particular understanding. In Jabr the shaykh goes on to note that most people are unable to know the detail of God's wise purpose. He adds that even the angels could not discover God's purpose in creating human beings who would shed blood (Q. 2:30). The angels had to be content with general knowledge and belief. ${ }^{59}$

\footnotetext{
Minhāj, 5:416/3:104.

6 Minhāj, 3:176-7/2:33.

$7 \mathrm{Jabr}, \mathrm{MF} 8: 511$.

Jabr, MF 8:513.

$59 \mathrm{Jabr}, \mathrm{MF}$ 8:513-4.
} 
The shaykh says much the same thing about angelic knowledge of human nature in Hasana. In God's great wise purpose and mercy, He created evil to be an inevitable constituent of humanity. Reminiscent of Ibn Sīnās assertion that fire would not be fire without burning, Ibn Taymiyya maintains that human beings would not be human had God created them differently and God's wise purpose would not have been realized. Yet, not even the angels, much less humans, know why this is so. ${ }^{60}$ Despite the shaykh's agnosticism concerning God's wise purpose in this particular passage, he provides more indications in Hasana than I have found elsewhere as to what he believes God's wise purposes in the creation of evil to be. He also tells his readers in Hasana that he has expounded the wise purpose and mercy in God's creation of Iblis and Hell in another place, but I have failed to locate this in the shaykh's works. ${ }^{61}$

In Hasana Ibn Taymiyya gives relative evil the educational function of deterrence and guidance away from the wrong path. God's destruction of Pharaoh and his people was evil relative to them, but it served the universal good as a lesson from which future generations might profit. In this regard, the shaykh quotes quranic verses dealing with Pharaoh and his people, "So, when they angered Us, We took vengeance on them and We drowned them all together. We set them as a precedent and an example to later generations" (Q. 43:55-6); and, "Truly, in this is a lesson for those who fear" (Q.79:26). ${ }^{62}$ Other quranic stories also promote human benefit in that they provide lessons upon which we may reflect and recognize in ourselves something of the disbelief that plagued earlier generations. ${ }^{63}$ Human sin in general serves as a lesson to others by evoking reflection, guidance, and belief. However, the shaykh adds that we should ask God not to make us into an object lesson of this kind. ${ }^{64}$

Ibn Taymiyya also notes that God sends prosperity and adversity, as well as tumult or earthquake (zalzäl), to test believers, purify them from evil, expiate their sins and increase their reward through patience. The blessing of prosperity may in fact be a greater trial than adversity. ${ }^{65}$ In support of these notions, he quotes the following texts among others: "That God might try what was in your breasts and that He might purify what was in your hearts"

\footnotetext{
60 Hasana, MF 14:315.

61 Hasana, MF 14:300-1.

62 Hasana, MF 14:276.

63 Hasana, MF 14:321-2.

64 Hasana, MF 14:307.

65 Hasana, MF 14:254-5 and 304-5.
} 
(Q. 3:154);66 "It may be that you hate something that is good for you, and it may be that you love something that is evil for you. God knows, but you do not know" (Q. 2:216); ${ }^{67}$ and the hadith, "I seek refuge in You from the trial of poverty and the evil of the trial of wealth." ${ }^{\prime 8}$ Also, when discussing God's use of an unjust ruler to ward off even greater injustice, Ibn Taymiyya explains that this injustice expiates the sins of those afflicted by it and increases their reward. He adds, "In [afflictions] they return to God, ask His forgiveness and turn to Him in repentance." ${ }^{69}$

In Hasana Ibn Taymiyya argues, as he does in Minhäj, that evil deeds are a precondition to the virtues of humility and repentance. He makes this point when taking up the hadith, "God did not decree anything for the believer except what is good for him." ${ }^{70}$ How could God's decree of evil deeds inducing punishment be good for the believer? The shaykh first asserts that the hadith appears to be referring to blessings and afflictions and to prosperity and adversity, not to human deeds. However, he then considers the possibility that the hadith encompasses God's decree of human sins as well. He explains that this is good for the believer because it leads to the further good of repentance that could not otherwise occur. The believer is not one who avoids sins entirely, but one who does not persist in them and repents to his own greater good:

The believer is he who does not persist in a sin but repents from it. Thus, it becomes a good deed.... He does not cease repenting from it until he enters Paradise by means of his repentance from it. A sin necessitates a servant's humility, his subjection, invocation of God, his asking Him for forgiveness and his bearing witness to his poverty and to his need for Him and that no one can forgive sins except Him. Because of the sin, good things happen to the believer that would not have happened without this. Therefore, this decree is good for him. ${ }^{71}$

${ }^{66}$ Hasana, MF 14:255.

${ }^{67}$ Hasana, MF 14:304.

${ }^{68}$ Bukhārī, 5899, Al-Da'awāt, Al-Isti'ādha min fitnat al-ghinā, in Hasana, MF 14:305.

${ }^{69}$ Hasana, MF 14:269.

70 Ảhmad, 12439, Bāqī musnad al-mukaththirīn, Musnad Anas b. Mālik. Ibn Taymiyya, Mahabba 156, also discusses this hadith in the context of God trying believers with both prosperity and adversity.

${ }^{71}$ Hasana, MF 14:318-9. This focus on the goodness of sin with repentance in Hasana correlates with the findings of Shahab Ahmed, "Ibn Taymiyyah and the Satanic verses," 86-7 and 90-100, concerning Ibn Taymiyya's view of prophetic protection ('isma) and the exemplary repentance of the prophets. According to Ahmed, the shaykh regards prophetic 'isma not as complete protection from committing sins (the widespread Sunnī belief in medieval and modern times) but as protection from persisting in sins already committed. In Ibn Taymiyya's view, the prophets, including the Prophet Muhammad, sinned, but they 
Here, as in other brief notes on the good of evil examined above from Hasana and Minhäj, the good in evil and one's own adversity and sin is the opportunity afforded to advance in the religious life. Elsewhere, Ibn Taymiyya notes as well that the unbelief of unbelievers is a blessing for believers in that it gives them occasion for jihād and moral exhortation. Similarly, the existence of satans provides believers opportunity to gain the highest rewards and spiritual levels through striving, showing enmity and resisting caprice. ${ }^{72}$ However, Ibn Taymiyya does not go on in Hasana or any other text to my knowledge to note the implications for God in the fashion of his close disciple Ibn Qayyim al-Jawziyya, who explains that sins and disobedience afford God Himself the occasion to demonstrate His mercy and forgiveness and that God's joy in repentance depends upon there being something from which human beings repent. ${ }^{73}$ Concern to protect God's self-sufficiency is probably what prevents Ibn Taymiyya from speaking of the vicissitudes of creatures giving God opportunity to exercise His attributes.

Whatever be the case, the shaykh does maintain in Hasana that everything that God creates is a blessing to His servants revealing His wisdom, mercy and power. He adds, "In everything that God creates is beneficence to His servants for which $\mathrm{He}$ is praised with the praise of thanksgiving. And in it He has a wise purpose that returns to Him because of which He has a right to be praised for it with a praise to which $\mathrm{He}$ has a right in His essence." ${ }^{.74} \mathrm{~A}$ little later in Hasana, Ibn Taymiyya complements this with, "In everything that $\mathrm{He}$ creates, $\mathrm{He}$ has a wise purpose, and $\mathrm{He}$ is praised for [what $\mathrm{He}$ creates] in consideration of that wise purpose." 75 Although the shaykh does not put it so simply, it seems clear enough that God is praised not only for His beneficence to creatures but also for His essence in which wisdom is inherent. Ibn Taymiyya then criticizes the Qadarīs (i.e. Mu'tazilīs) for asserting that

immediately repented from their sins and did not remain in them. Through sin and repentance, the prophets attained greater perfection (kamäl) than they could otherwise have attained. This pattern of immediate repentance from sins then serves as an example for all believers to follow, and it nurtures the devotional virtues of repentance and asking for forgiveness. It might be thought that Ibn Taymiyya encourages sinning in order to gain the greater good of repentance. However, Ahmed, 93 n. 64, highlights, but does not translate, a text in Minhäj, 2:400/1:227, where Ibn Taymiyya cautions against this. The passage reads, "There is no doubt that evil deeds are not commanded, and it is not for the servant to commit them in order thereby to repent from them.... [This is] like someone who wants to eat poison and then drink the antidote. This is ignorance."

${ }_{72}$ Mahabba, 160.

73 Ibn Qayyim al-Jawziyya, Shifäa al-'alìl, 486.

${ }^{74}$ Hasana, MF 14:301-315 (quote on 302).

75 Hasana, MF 14:309. 
God creates with wise purpose to the profit of creatures but without return to Himself. With such a God, praise is nothing more than thanksgiving for profit gained, and consideration is given neither to His sovereignty nor to confessing His exclusive divinity (tawhìd al-ilähiyya), that is, His right to worship in His essence. Additionally, Ibn Taymiyya condemns the Jahmīs (i.e. Ash'arīs) for holding to God's sovereignty and exclusive lordship (tawhid al-rubübiyya) without confessing His wisdom or exclusive divinity. The Jahmī God who creates pure evil devoid of wise purpose, profit and mercy is worthy of blame and has no right to praise or love. Rather, "[Praise] is for His blessing, and it is worship of Him for His divinity, which includes His wise purpose. ${ }^{.76}$

This discussion of the Hasana material has drifted from God's wise purposes in the creation of evil onward to God's essence and divinity, thus reflecting Ibn Taymiyya's keenness to affirm not only wise purposes in God's acts but also, more profoundly, the wise purpose inherent in God's essence and God's praiseworthiness in that. For Ibn Taymiyya, God's right to worship is essential, and it is from this that His wise purpose flows, even to His creation of evil, which serves to expiate sin, guide human beings and nurture religious virtues such as humility and repentance that lead to recognition of His exclusive divinity. In this light, the shaykh's interpretation of evil is very much that of the Sufis for whom it is God's tool of discipline for spiritual growth.

\section{Ibn Taymiyya's Location of the Origin of Evil in Nonexistence ('adam)}

In texts examined in Chapter Four, Ibn Taymiyya deems the substrate principle a sufficient defense of God's justice in creating and punishing human bad deeds. God is not qualified with the bad deeds that $\mathrm{He}$ creates and $\mathrm{He}$ is just to punish these acts because $\mathrm{He}$ creates them in a substrate other than Himself. In two major theodicean texts-Hasana and Fätiha-Ibn Taymiyya goes beyond the substrate defense of God's justice and attempts to free God entirely from creating gratuitous evil deeds by locating their origin in nonexistence. The following two sections examine how the shaykh employs nonexistence to deal with the origin of evil in Hasana and Fätiba, respectively. Rooting evil in nonexistence probably represents a development

\footnotetext{
${ }^{76}$ Hasana, MF 14:309-313 (quote on 311).
} 
in Ibn Taymiyya's thought, but this cannot be shown definitively due to difficulty in establishing a precise chronology for his theodicean writings.

\section{Exclusive Divine Goodness and the Origin of Evil Deeds in Hasana}

\section{Interpreting Q. 4:78-9: Everything Is from God; Evil Is from the Soul}

Precedents for the notion of evil as privation or nonexistence ('adam) are found in Ibn Sīnā and Ibn 'Arabīi. ${ }^{77}$ Whereas these thinkers draw on the concept of privation primarily for metaphysical reasons, Ibn Taymiyya employs it in Hasana to address a more typically Mu'tazili concern, that of upholding God's order of retribution and absolving God of being the ultimate source of moral evil. Some material from Hasana has already been examined in this and previous chapters, but the central problem of the treatise-the origin of evil-has yet to be addressed. Much of the text wrestles with an apparent contradiction posed by two quranic verses that occur in a context of commanding jihad and blaming those who try to evade it (Q. 4:65-104). ${ }^{78} \mathrm{Ibn}$ Taymiyya writes:

One group thought that there was in the verses an ambiguity or contradiction in the outward sense where [God] says, "Everything is from God" (4:78), and then differentiates between good things (basanät) and evil things (sayyi'ät). He said, "Any good thing that comes to you is from God and any evil thing that comes to you is from yourself (min nafsika)" (Q. 4:79). This is due to their insufficient understanding and their not meditating on the verses. In these verses is no contradiction (tanāqü $)^{79}$

If God is the source of all things, do not evil things also come from Him and not from creatures? Ibn Taymiyya does not specify the group posing this contradiction, but he does mention earlier Kalām attempts to resolve it. The shaykh cites a Mu'tazilī proposal that Q. 4:79 refers to God's command. On this reading all good comes from God only in the sense that He commands it. He does not necessarily create it. The nafs, which I will translate variously as "self," "soul" or "person," creates both obedience and disobedience and is thus the source of evil things. Ibn Taymiyya rejects this

77 For references in Ibn Sīnā and Ibn 'Arabī, see above at the beginning of this Chapter. Fakhr al-Dīn al-Rāzī also elaborates on evil as nonexistence in one of his works, his philosophical al-Mabāhih al-mashriqiyya, 2:519-523. Al-Julaynad, Qadiyyat al-khayr wa al-sharr, 161-4, explains that al-Rāzī's departs from Ash'arī tradition with these ideas.

78 Ibn Taymiyya, Hasana, MF 14:229-233, surveys the context that these verses constitute for Q. 4:78-9.

79 Hasana, MF 14:248-9. 
interpretation because "Everything is from God" (Q. 4:78) precludes human beings creating their own acts. ${ }^{80}$

The shaykh also notes an interpretation that he traces to the Ash 'ari theologian Abū Bakr b. Fūrak (d. 406/1015). In this view, the end of Q. 4:79 should be read as an interrogative, "Any evil thing that comes to you, is it from yourself?" which must be answered negatively because all things come from God. Ibn Taymiyya discards Ibn Fūrak's interpretation as grammatically untenable. The shaykh argues instead that the verse refutes any depreciation of the human role in acts because it indicates that at least some deeds come from the person himself. ${ }^{81}$

In a brief discussion of these verses in Irāda, Ibn Taymiyya interprets good things and evil things as strictly blessings and afflictions. The evils of affliction are only from the person in the sense that God sends them as punishment for sins that God also creates. The shaykh states clearly that good things and evil things are not acts of obedience and acts of disobedience, respectively, such that God could be said to create the former but not the latter. ${ }^{82}$ In Hasana, however, he locates the ultimate source of disobedient acts more firmly in human beings. While hasanät and sayyi $\bar{a} t$, which I have been translating "good things" and "evil things" respectively, do refer to blessings and afflictions, Ibn Taymiyya argues that they may also be said to include obedience and disobedience. For this reason, I will sometimes translate hasanāt and sayyi āt as "good deeds" and "evil deeds." In this light, the shaykh reads Q. 4:79 to mean that obedience is a blessing that comes to a person from God while disobedience is an affliction that comes to him because he himself, in some sense, does it. ${ }^{83}$

Ibn Taymiyya explains this interpretation by drawing a distinction between a deed and its recompense ( $j a z \vec{a})$ of punishment or reward. God may punish a first act of disobedience with a second act of disobedience, and He may reward a first good deed with a second good deed. The shaykh illustrates this from the Qur'an at length. Three of his quotations will suffice here: "By [the Book], God guides whoever follows His good-pleasure in the ways

${ }^{80}$ Hasana, MF 14:246-7, 258-9. Gimaret, Théories de l'acte humain en théologie musulmane, 347-352, surveys this and other interpretations of 4:78-9 found in the classical Kalām and tafsir literature.

${ }^{81}$ Hasana, MF 14:247, 421-4.

82 Iräda, MF 8:114-7.

${ }^{83}$ Hasana, MF 14:234-9. Similar interpretations of 4:78-9 may be found in the commentaries of al-Tabarī, Tafsìr al-Tabarì: Jämi al-bayān 'an ta' wìl äyy al-Qur' ān, ed. Mahmūd Muhammad Shākir (Cairo: Dār al-Ma ārif bi-miṣr, n.d.), 8:555-560; and Abū al-Qāsim Jār Allāh al-Zamakhsharī, Al-Kashshāf (Beirut: Dār al-kutub al-'ilmiyya, 1415/1995), 4:527. 
of peace" (Q. 5:16); "Then the unbeliever was confounded. God does not guide people who are unjust" (Q. 2:258); and, "We shall turn their hearts and their eyes, as they did not believe in it the first time, and We shall leave them in their insolence to wander blindly" (Q. 6:110). From this evidence that God rewards and punishes deeds with other deeds similar in kind, the shaykh concludes that the key phrase at the end of Q. 4:79, "from yourself," encompasses both sins gratuitously perpetrated and God's creation of evil deeds as punishment. As for good deeds, however, God creates both the acts and their recompense in keeping with "Any good thing that comes to you is from God." ${ }^{4}$

Having established that evil things originate only in the very person afflicted, Ibn Taymiyya refutes a charge that the Prophet and his message are sources of evils and afflictions, as in Q. 4:78: "If a good thing comes to them, they say, 'This is from God', and if an evil thing comes to them, they say, 'This is from you [Muhammad]'. Say, 'Everything is from God." The shaykh invokes the context of this verse in the Muslim setback at the Battle of Uhud and places the blame for its afflictions not on the Prophet but on the sins of the Muslims. ${ }^{85}$

\section{All Good Comes from God's Unmerited Blessing}

Even though Ibn Taymiyya imbues "Any evil thing that comes to you is from yourself" with a strong sense of retributive punishment in Hasana, it is difficult to see how this fits with his conviction that both good and evil deeds are created and predetermined by God. What is the sense in which human beings are the sources of their evil deeds? The shaykh himself presents the problem clearly:

If acts of obedience and acts of disobedience are predetermined (muqaddar) and blessings and afflictions are predetermined, then what is the difference between good things, which are blessings, and evil things, which are afflictions, so as to deem the one from God and the other from the human soul? ${ }^{86}$

In response, Ibn Taymiyya elaborates a series of eight "differences ( furüq)" between good things and evil things. ${ }^{87}$ The fourth and eighth differences do not address the question directly and may be summarized briefly. The

\footnotetext{
${ }^{84}$ Hasana, MF 14:239-247.

85 Hasana, MF 14:248-254, 342. Cf. Hasana, MF 14:373-5.

${ }^{86}$ Hasana, MF 14:259.

87 These eight differences vary in length from one paragraph to fifty-four pages in the printed text. The one-paragraph discussions are the first (MF 14:260) and the third (MF 14:265). The fifth is the longest (MF 14:277-331). The eight discussions together take
} 
fourth observes that evil is relative and provides a three-fold evil attribution typology along lines examined earlier in this chapter. ${ }^{88}$ The eighth difference says simply that disgusting circumstances are appropriate for those who do disgusting things (khab-ith). It is not fitting for such people to reside in Paradise as Paradise is only appropriate for those who have been purified from their sins. ${ }^{89}$

The remaining differences work toward resolving the contradiction. In the first three and the seventh, Ibn Taymiyya underscores God's great beneficence. God distributes blessings (sg. ni $m a$ ) and grace ( $f a d l$ ), such as health, guidance, belief and good deeds, apart from consideration of human worthiness, and God brings people into Paradise out of pure grace without respect to their deeds. With respect to evil deeds, moreover, God limits His punishment strictly to what retribution requires. ${ }^{90}$ The following passage from the second difference epitomizes this perspective:

All that intelligent beings enjoy of the two goods of this world and the hereafter is pure blessing from Him without a preceding cause making it their right. They have neither might nor strength from themselves except through Him. $\mathrm{He}$ is Creator of their souls, Creator of their righteous deeds and Creator of recompense. So, His statement, "Any good thing that comes to you is from God" (Q. 4:79), is true in every respect, in the outward sense and the inward sense, according to the doctrine of the Sunnis. As for an evil thing, it is only from the sin of the servant, and the sin is from himself. [God] did not say, "Truly, I did not predetermine this, and I did not create it." Instead, He mentioned to human beings what profits them. ${ }^{91}$

According to Ibn Taymiyya, the profitable thing that God has mentioned is the latter part of Q. 4:79: "Any evil thing that comes to you is from yourself." "From yourself" benefits humankind by prompting repentance and entreaty for forgiveness of sins. With this in mind, the shaykh interprets "Everything is from God" (Q. 4:78) to mean that blessings, afflictions and acts of obedience and disobedience are all from God. The second verse (Q. 4:79) then differentiates between blessings and evil in order to motivate thanksgiving to God for the former and seeking forgiveness from Him for the latter. ${ }^{92}$ This interpretation involves a shift from a retributive scheme of reward for good

up just under half of Hasana, specifically 87 out of 197 pages in the printed text (MF 14:259-346).

${ }^{88}$ Hasana, MF 14:266-277.

89 Hasana, MF 14:343-6.

90 Hasana, MF 14:260-5, 339-342.

91 Hasana, MF 14:261.

92 Hasana, MF 14:261-5. A similar argument is made in Hasana, MF 14:319-320. 
deeds to a logic of pure grace and blessing in which God is the sole source of all good. The substrate principle noted in Chapter Four above no longer applies in good deeds. Good deeds are not attributed to the human in whom God creates them to subsist but to God's unmerited blessing. Retribution is left to operate strictly on the level of evil deeds. This interpretation of Q. 4:78-9 may nurture a reverent attitude toward the goodness of God, but it does not explain how pure grace in good deeds coexists with retribution in evil deeds.

\section{The Source of Evil Deeds Is Ignorance, which Is Nonexistent}

Ibn Taymiyya grapples with the logic of reward and punishment more extensively in the fifth and sixth differences in Hasana, vacillating at first between retributive based and blessing based approaches to reward before concentrating on a retributive scheme in punishment. At the beginning of the fifth difference, the shaykh explains that all good deeds with which God blesses human beings are existing things (umür wujüdiyya). Furthermore, omission (tark) of what is prohibited is just as existent as obedience to a command. Omission of a prohibited act is existent because it involves a person's "knowledge that it is a bad sin and that it is a cause of chastisement, his loathing and his hatred of it, and his restraint of himself from it when he desires it, craves it and seeks it.." ${ }^{93}$ Ibn Taymiyya then speaks retributively, noting that human beings are only rewarded for good deeds if they undertake them with explicit intention and love for God. Similarly, they are only rewarded for omitting evil deeds if they omit them out of hatred for them and loathing for worship of any apart from God. Moreover, there is no reward for omitting a forbidden deed that one never thought to commit, and there is no punishment for omitting to do what is commanded unless there is a perverse refusal to obey. Reward and punishment apply only to the existent-or we might say intentional—commission of good deeds and evil deeds, respectively. There is neither reward nor punishment for someone who does not know that his deeds are good or evil. Such a person is in a state of unaccountability similar to that of children and the insane. The shaykh ends this part of his discussion by turning from the retributive perspective to that of God's unmerited blessing. All rewarded good deeds are existent and a blessing from God: "It is He who makes belief beloved to the believers

\footnotetext{
${ }^{93}$ Hasana, MF 14:278.
} 
and adorns it in their hearts, and [it is He] who makes disbelief, iniquity and disobedience hateful to them." ${ }^{94}$

Ibn Taymiyya returns to retribution in the fifth difference by tracing evil deeds variously to injustice, heedlessness (ghafla), craving (shabwa), caprice ( haw $\bar{a}$ ), Satan and the soul's hatred for what is obligatory. However, he roots evil deeds ultimately in ignorance or the lack of knowledge. God has created humans in their natural constitution ( fitra) to love knowledge and to gain what profits them and gives them pleasure. Moreover, God has given His guidance: "God-Exalted is $\mathrm{He}$-has guided humanity with general guidance by the knowledge and the means of knowledge that He put in the natural constitution and by the books He sent down to them and the messengers $\mathrm{He}$ sent to them." 95 Moreover this guidance and knowledge will restrain from evil. Human beings will decide to perform good deeds and avoid evil deeds if they are adequately aware of the profit entailed in doing so: "The root of what makes people fall into evil deeds is ignorance and not knowing that they will harm them with preponderant harm, or thinking that they will profit them with preponderant profit." 96 The shaykh argues that a thief will not steal if sure of getting caught and an adulterer will not commit adultery if certain of being stoned. Wine drinkers, however, present a more difficult problem. Ibn Taymiyya observes that punishment does not necessarily stop them from drinking. However, he does not explore why this is so; instead, he notes that the death penalty may be necessary for the inveterate drinker. ${ }^{97}$

It is difficult to reconcile Ibn Taymiyya's view of ignorance as the source of evil with his notion that only perverse and existent disobedience is punished retributively. On the one hand, and as noted in the preceding paragraph, he argues that human beings given proper guidance will necessarily do what they should since this will be the course of action most profitable for them. He believes that they will never perversely disobey God in full awareness of the consequences, and he does not allow the observation of incorrigible wine drinkers to disturb this conviction. No one will disobey knowing full well that it will lead to his own ruin. Perversity is therefore impossible. On the other hand, Ibn Taymiyya explains that punishment is due only for the existent omission of obligatory deeds, that is, for disobedience that is perverse and intentional. Now the difficulty is this: If a knowledgeable person will not disobey, and if a person who disobeys does so only for lack

${ }^{94}$ Hasana, MF 14: 277-287 (quote on 287).

95 Hasana, MF 14:296.

96 Hasana, MF 14:290.

${ }^{97}$ Hasana, MF 14:287-294. 
of knowledge and proper guidance, then there will be no justly administered retributive punishment because no act of disobedience is truly perverse. ${ }^{98}$ The disobedient is always ignorant and therefore unaccountable. The notion that lack of knowledge is the fundamental root of evil deeds renders a retributive scheme that punishes only existent or perverse deeds superfluous. Punishment, however, may be administered for other than retributive reasons, such as deterrence and education, which make evil deeds and their consequences known for what they are: harmful to the human soul. As observed above, Ibn Taymiyya does indeed supply these kinds of reasons in Hasana.

The evident reason that Ibn Taymiyya locates evil deeds in ignorance and lack of knowledge is to clear God of being the source of evil. Continuing in the fifth difference, he argues that the nonexistence that is ignorance and lack of knowledge is nothing at all. It has no agent and therefore cannot be attributed to God. God is the source only of existent things, not of ignorance. ${ }^{99}$ In the same context, the shaykh explains that God creates the soul constantly willing and moving. When it does not turn toward God in its ignorance, it necessarily turns away from Him and worships something else. Such a person suffers recompense through not "living the profitable life for which he was created." ${ }^{100}$ Yet, it remains unclear how the God who creates all human acts can hold human beings responsible for their ignorance, and it is not apparent why human beings lack adequate knowledge in the first place. Ibn Taymiyya concludes the fifth difference in Hasana by discussing the attribution of evil to its final cause, that is, to wise purpose, and to its agent or secondary cause, as was noted above. With this, the shaykh looks away from the origin of evil to God's wise purpose in all created things.

\section{Punishment Is for a Lack of the Deeds for which One Was Created}

In the sixth difference, Ibn Taymiyya returns to the problem of evil's ultimate source and makes his final and fullest attempt in Hasana to explain how God is just to punish human sins retributively. Substantial portions of this discussion are translated below. Ibn Taymiyya begins, "The existent sins (al-dhunūb al-wujüdiyya) by which the servant is tried-even if they are a creation of God-are his punishment for his not doing what God created

98 Aspects of the problem outlined here are not unique to Ibn Taymiyya. According to Hourani, Islamic Rationalism, 92-7, the Mu'tazilī theologian 'Abd al-Jabbār argues that humans will not do bad deeds if they know both that such deeds are evil and that there is no advantage to be gained in doing them.

99 Hasana, MF 14:294.

100 Hasana, MF 14:297. 
him to do and what He constituted him naturally to do." ${ }^{101}$ The fundamental problem is the failure of human beings to commit the good deeds for which they were created and the deeds that humans should know to do through the guidance of their natural constitutions. In order to free God from responsibility for having created this failure and to render Him just in punishing it retributively, Ibn Taymiyya calls it a nonexistent that God does not create. This nonexistent is not punished with the complete punishment of the Fire, but it is punished by God's creation of evil deeds. The shaykh explains that this is a middle position between complete punishment for a pure lack of good deeds, a view he attributes to the Mu'tazilī Abū Hāshim al-Jubbā'ī (d. 321/933), and complete punishment of only existing evil deeds such as the intentional omission of good deeds. ${ }^{102}$ He elaborates:

What has been mentioned in this respect is a median position (amr wasat). That is, [God] punishes [the servant] for this lack [of good deeds] with his commission of evil deeds, not with [complete] punishment of them. He does not punish him for them until He sends His messenger. When he disobeys the messenger, at that moment he deserves complete punishment. At first, he is only punished by that from whose evil he can be saved by repenting or by not being held accountable. He is like a boy who does not occupy himself with what profits him but with what is a cause of his harm. However, the pen of sinful things will not write anything against him until he reaches the age of accountability. When he reaches the age of accountability, he will be punished. Then, the evil deeds to which he has grown accustomed may be a cause of his disobedience after reaching the age of accountability. He has not been punished except for his sin, but he only deserves the conventional punishment after being made accountable. As for his preoccupation with evil deeds, this is punishment for his not committing good deeds.

Hence, evil is not [attributed] to God in any respect. Even if God is the Creator of the servants' acts-His creation of obedient acts is blessing and mercy, and He has a wise purpose and mercy in His creation of evil deeds - this is nonetheless just of Him. He is not unjust to humans at all, but humans are unjust to themselves. Their injustice to themselves is of two kinds: their not committing good deeds - this is not attributed to Him—and their commission of evil deeds-He creates them as their punishment for omitting to commit

101 Hasana, MF 14:331.

102 Hasana, MF 14:333. Ibn Taymiyya, Hasana, MF 14:281-2, takes an explicit position against Abū Hāshim al-Jubbāà who says that failure to fulfill an obligation is not an act at all. Abū Hāshim's father Abū 'Alī took the opposite position (i.e. that adopted by Ibn Taymiyya), saying that omission of a duty is in itself a real act. Both father and son agree, however, that God punishes failure to fulfill duties. For a brief description of the controversy, see Martin J. McDermott, The Theology of al-Shaikh al-Mufid (d. 413/1022) (Beirut: Dar el-Machreq, 1978), 157-9. 
the good deeds for which He created them and which He commanded them. Every blessing from Him is grace, and every vengeance from Him is just.

It will become clear to whoever meditates on the Qur'an that, generally, God makes whatever He mentions in the way of creating unbelief and acts of disobedience as a recompense for these deeds. [This is] as in His statementExalted is He-"Whomever God wills to guide, He opens his breast to Islam. Whomever He wills to misguide, He makes his breast narrow and tight as if he were climbing up to the sky. In this way, God makes an atrocity for those who do not believe" (Q. 6:125). And He-Exalted is He-says, "So, when they turned away, God turned their hearts away" (Q. 61:5). And He-Exalted is He-says, "As for him who is a miser and self-sufficient and belies goodness, We will ease his way into hardship" (Q. 92:8-10). In this and similar examples they executed deeds by which He punished them for committing what was forbidden and omitting what was commanded. These things were only from them and created in them because they did not do that for which they were created. They must inevitably have motion and a will. When they were not active with good deeds, they were active with evil deeds out of God's justice since He put this in its place, in its substrate, which is susceptible to it, namely, the heart, which is not [existent] except [as] committing deeds. If it does not commit a good deed, it will be employed in committing an evil deed. As it was said, "As for your soul, if you do not occupy it, it will occupy you."103

Following this, Ibn Taymiyya briefly notes that Jabrīs assert that God could punish unbelief and disobedience that $\mathrm{He}$ creates without wise purpose and that Qadarīs maintain that humans create their own acts. He also mentions that many Qadarīs allow God to create sins in recompense but do not permit God to create the first sin that a person commits lest God be unjust to punish it. ${ }^{104}$ Ibn Taymiyya likewise excludes the first sin from the realm of God's creation, but, unlike the Qadarī, he also does not attribute its creation to the human. He maintains that it is not created by anyone because it is not an existent. Rather, it is the nonexistence of the good deeds for which the human was created. The first sin in the life of each individual human being is a passive failure to cooperate with God's intention for him. It is a privation of what God meant human beings to do and be, and this privation has neither a divine nor a human agent. In the following passage from the sixth difference in Hasana, the shaykh elaborates this and then briefly addresses why humans do not do that for which they were created in the first place:

What we have mentioned necessitates that God is Creator of everything. Nothing originates except by His will and power. Nevertheless, the first of the existing sins is the [one] created, and this is a punishment for the servant's not

103 Hasana, MF 14:333-5.

104 Hasana, MF 14:335-6. 
doing that for which he has been created and that which he is supposed to do. It is not permissible to attribute this lack to God. It is not anything so that it would enter into our statement, "God is the Creator of everything." The first of the existent sins that $\mathrm{He}$ originates is a punishment of the servant for this lack. The rest [of the sins] may either be a punishment of the servant for what exists or they may be a punishment for his continuation in [this] lack. As long as he does not consecrate deeds to God, he is still an associationist, and Satan still has authority over him.

Then, His specification (takbsīs) - Glory be to Him - of whom He guidesto employ him from the beginning in that for which he was created and not so to employ another-is a specification of His by His grace and mercy. Therefore, God says, "And God chooses whomever He wills for His mercy. God is the owner of abounding grace" (Q. 2:105). In this is wise purpose and mercy about which He knows better, as when He specifies some bodies (abdān) to have strengths not found in others. Because of the lack of strength, [a body] might suffer diseases that are existent and other than that in His wise purpose. By verifying this, [the servant] wards off the obscurities of this subject, and God knows better what is correct. ${ }^{105}$

Locating the origin of evil in the nonexistent failure of human beings to do that for which they were created may succeed in granting some semblance of libertarian freedom and establishing a basis upon which to mete out retributive punishment. However, making nonexistence the origin of this failure does not explain convincingly why human beings fall passively into their initial sins. In the passage above, the shaykh appears to sense these problems, and he turns away from arguing on the plane of retribution and shifts back to God's grace and wise purpose. Ultimately, there is no explanation for human weakness but God's wise purpose and mercy. Ibn Taymiyya's attempt to find a basis for retributive judgment in nonexistence still has its further grounding in God's wise purpose in setting up the creation as He has and in creating some human beings to dissipate their energies in unprofitable deeds.

\section{Call on God Alone Because He Is the Sole Source of Good}

Summing up the previous subsections, Ibn Taymiyya's dominant viewpoint on God's recompense in Hasana differs substantially from that of the substrate principle in which the good and bad deeds that God creates are both attributed to human beings. With the substrate principle, retributive justice operates in both good and bad deeds from the human perspective, while God from the divine perspective creates everything according to His wise purpose. In Hasana, however, the shaykh often maintains that humans should take

\footnotetext{
105 Hasana, MF 14:336-7.
} 
the perspective of God's all-comprehensive goodness in blessings and good deeds but the human retributive perspective in evil deeds and afflictions. Good things point to God alone, not to human achievement, while evil things always point to lack and failure in the individual afflicted. Neither God nor human beings create this failure; it has no agent. Yet, human beings are responsible for allowing this failure to occur to them, and they suffer the punishment of God creating evil deeds in them as retribution.

The shift from the substrate principle to God as the unique source of all human good deeds also carries ethical and spiritual import for Ibn Taymiyya in Hasana. Noted above was his claim that Q. 4:79 indicates what is profitable for human beings: the conviction that all blessings come from God evokes thanksgiving, while knowledge that evil deeds come only from the soul promotes seeking forgiveness. In the latter parts of Hasana, he also contends that no intercession (shafä $a$ ) should be sought except from those to whom God gives authority to intercede before Him, and he criticizes beliefs and practices that he believes violate God's Law and detract from calling on God alone. While God has a right to worship in His very essence, it is also the case that, as the sole source of all good things, He should be the sole object of complete trust, hope, praise and invocation. ${ }^{106}$

\section{The Origin of Evil in Human Imperfection and Lack in Fātiha}

Whereas the shaykh introduces the notion of evil as nonexistence in Hasana primarily to solve a rational difficulty dealing with retribution, he elaborates it in Fätiha with much greater philosophical detail and analysis to make a religious argument. Fätiḩa opens with a full treatment of complete trust in God and God's exclusive and essential right to worship. This constituted a key source for my discussion of "worship" and "asking for help" found above in Chapter One. ${ }^{107}$ Following this, Ibn Taymiyya takes up evil in order to argue that, since no good comes from creatures, appealing to them for help is like seeking aid from nothing at all. Thus, human weakness, imperfection, and ultimately nonexistence show that God alone should be sought for help. ${ }^{108}$

Ibn Taymiyya begins the part of Fätiha on evil by affirming that God is Creator of all existent things. The human soul contributes only nonexistence, which is nothing at all and requires no agent. Now, according to the shaykh,

106 Hasana, MF 14:314-5, 341, 359-421.

107 Fätiba, MF 14:4-15.

${ }^{108}$ Fätiha, MF 14:15, 29. 
the nonexistence of something may be due to the lack of an entailing factor (muqtadī) or the existence of an impediment (māni $\left.{ }^{i}\right)$. However, God's will $(m a s h \vec{i} a)$ is always decisive in necessitating the existence of something: "The will of [God] is the perfect cause (al-sabab al-kamil). With its existence there is no impediment, and with its nonexistence there is no entailing factor." With these metaphysical bases in place, the shaykh explains that all good comes from God and that no good comes from the soul. ${ }^{109}$

Ibn Taymiyya then identifies two kinds of evil: the nonexistent and the existent. ${ }^{110} \mathrm{He}$ explains that a nonexistent evil may be the nonexistence of an essence, the privation of an attribute of perfection such as life, knowledge, speech and the like, or a lack of good deeds such as loving and turning to God. The existence of such things is good, and their privation is evil. However, this privation has no agent or creator. Thus, it is not attributed to God but to the soul as a concomitant of the way God created it. In other words, evil, imperfection and privation are essential elements of human nature:

[This privation] is only from the necessary concomitants of the soul, which is the reality of the human being, before it is created and after it has been created. Before it is created, it is nonexistent, which makes this privation follow necessarily. After it has been created-it having been created weak and imperfect-there is imperfection, weakness and impotence in it, and these things are nonexistent. They have been attributed to the soul as the attribution of the nonexistence of the effect to the nonexistence of its cause. ${ }^{11}$

Following this, Ibn Taymiyya again notes that the nonexistence of something may be due either to the lack of its agent or to an impediment, and, as before, he mentions that no impediment can impede God's will. However, he adds that God may create one thing to be a secondary cause (sabab), another thing an entailing factor, and yet another thing an impediment. In this case, the impediment impedes the cause until God makes the cause complete (tämm). With this in view, the shaykh explains, "These nonexistent evil deeds are only attributed to the servant, sometimes due to the lack of a cause from him, and at other times due to the existence of an impediment from him." The lack of a cause consists in servants having no strength and good in themselves. Impediments include impotence and preoccupation with deeds that logically preclude other better deeds. ${ }^{12}$

109 Fätiḥa, MF 14:15-7 (quote on 17).

110 Fätiha, MF 14:18-24.

111 Fätiha, MF 14:18.

112 Fätị̆a, MF 14:19-20 (quote on 19). 
Some discussion of the second kind of evil in Fatiha - existent evil-has already been given earlier in this chapter. This evil is not absolute, and, from God's perspective, it is wholly good by virtue of God's wise purpose. Following the three-fold evil attribution typology, however, it is also attributed to its secondary cause, and, "The secondary cause of this existent, particular, restricted evil is either nonexistent or existent." 113 As examples of the nonexistent type of secondary cause, Ibn Taymiyya notes the lack of a condition or the lack of part of a cause. This is as when a cause of pleasure and good is fully present, but the condition is lacking, which causes pain. More concretely, the lack of hearing causes the pain of deafness; the lack of health causes pain and illness; and so on. The shaykh clarifies furthermore that the servant commits forbidden acts and suffers their harm only out of ignorance and need which arise out of nonexistence, specifically, the nonexistence of knowledge and the nonexistence of sufficiency $($ ghin $\bar{a})$, respectively. As examples of existent secondary causes of existent evil, Ibn Taymiyya cites commission of forbidden deeds leading to punishment and blame, eating harmful foods and forceful movements inducing pain. These existents are imperfect because they do not cause pure good, and the shaykh traces them back to other lacks such as the lack of complete examination and listening, which themselves go back to either pure nonexistence or the impediments of pride and envy. Pride results from a vain imagination that arises out of the soul's lack of sufficiency in the Real, and envy originates in a lack of the level of blessing that would bring the envious on a par with the envied. Similarly, murder and adultery occur because someone cannot fulfill his need in some other way, and the source of this need is nonexistence. ${ }^{114}$ The distinction between nonexistent and existent causes of existent evil dissolves in the final analysis to nonexistence because the existent causes of evil are always imperfect, and imperfection itself is rooted in nonexistence.

Ibn Taymiyya elaborates further in Fätiha that pure nonexistence cannot cause existence and that existence is not a cause of nonexistence because nonexistence does not need an existent cause. He again notes that pure existence is completely good, and he then divides evil into pain on the one hand and causes of pain on the other. As an example of a cause of pain, he notes evil deeds leading to chastisement. Pain results from a privation, as in the separation of something that should be connected. Sins that cause pain arise initially from not meeting obligations, which opens the door to

113 Fätiba, MF 14:22.

114 Fätiḩa, MF 14:23-4. 
committing forbidden acts. The shaykh ends the section on evil in Fätiha by explaining that human beings should seek refuge in God from both the evil deeds they commit and the pain and punishment that these deeds bring. ${ }^{115}$ In the remainder of the treatise, he expands on the human need for God to be the object of his worship Whom he loves for His essence and on the need to rely totally on the God from Whom all blessing and help come. ${ }^{116}$

\section{Conclusion}

In the evil attribution typology presented at the beginning of this chapter, Ibn Taymiyya identifies three ways of speaking about evil. Reviewing these in reverse order, the third type consists in eliding the agent of evil, presumably God, and giving the respective verb in the passive voice. This is a rhetorical courtesy, which the shaykh does not elaborate further except to cite a few examples from the Qur'an. The second type diverts attention from the Creator and attributes evil solely to its secondary cause, that is, to the creature that commits it. The first type attributes evil to the generality of what God creates. This type is interpreted along Avicennan lines in three ways: evil is a necessary concomitant of God's creative activity; evil is harmful only relative to particular persons but wholly good by virtue of God's wise purpose in creating it; and evil is minuscule compared to the great quantity of good.

Ibn Taymiyya is often reticent to speculate on the specifics of God's wise purposes in the creation of evil, and he sometimes notes that it is sufficient to believe simply that God has a wise purpose in all that He does. In a few places, however, and especially in Hasana, the shaykh explains that evil has the educational function of deterring others from bad deeds and the religious functions of purifying through testing, expiating sins, providing opportunity to earn reward and developing virtues such as repentance, humility and devotion to God. In assigning evil these educational and spiritually nurturing roles, the shaykh adopts ideas found also among the Mu'taziliss and the Sufis.

The first two types in Ibn Taymiyya's evil attribution typology formalize a dichotomy between the divine and human perspectives. However, the shaykh does not explicate this paradoxically in the spirit of Ibn 'Arabī. Instead, he attempts to resolve the attendant rational difficulties. His interpretation of Q. 4:78-9 in Hasana provides a prime example of this. Ibn Taymiyya denies

115 Fätiha, MF 14:24-8.

116 Fätị̆a, MF 14:29-36. 
that there is a contradiction in these verses' claims that all is from God and that every evil thing is from the individual person afflicted. He resolves this most fully by locating the ultimate source of evil in the nonexistence or lack of the good deeds for which God created human beings. This lack cannot be attributed to the creative activity of God because a nonexistent has no agent, but God punishes people in whom this lack is found by creating evil deeds that preoccupy them from doing good deeds. However, there remains the question of why some people fall into a lack of good deeds. Here the shaykh implicitly acknowledges difficulty by switching back to the divine perspective and explaining that God chooses to employ some, but not others, in good deeds according to His mercy and wise purpose, just as He creates some to be stronger than others. Despite Ibn Taymiyya's denial of contradiction in Q. 4:78-9, his interpretation does not eliminate the contradiction in his doctrine between retribution on the one hand and God's mercy and wise purpose on the other.

A similar problem arises in Ibn Taymiyya's discussion of the basis for reward in Hasana. At some points, he grounds reward retributively in good deeds, but, at other points, he shifts this ground to God's unmerited grace in creating only blessings and good deeds. He then argues that God is the sole source of good and therefore the only worthy object of trust and worship. The same ideas are articulated more philosophically in Fätiha. The upshot is that piety and probably the concomitant injunction to give God the highest similitude nudge Ibn Taymiyya gently but firmly away from a retributive conception of good deeds. As a result, he limits retribution to evil deeds and grounds good deeds solely in God's grace and blessing. Perhaps as well the shaykh is simply working out the inherent logic of optimism. 